\title{
CARBONATE SURFACE SOLUTION IN THE CLASSICAL KARST ${ }^{(1)}$
}

\author{
Franco Cucchi ${ }^{\star}$, Fabio Forti ${ }^{\star \star} \&$ Furio Finocchiaro*
}

\section{RIASSUNTO}

Le ricerche attualmente in corso sulla dissoluzione delle rocce carbonatiche sul Carso di Trieste indicano che l'abbassamento medio delle superfici esposte agli agenti atmosferici è di $0.028 \mathrm{~mm} /$ anno con una piovosità media di $1350 \mathrm{~mm}$. I valori massimi $(0.031$ $\mathrm{mm} /$ anno) competono ai calcari microcristallini, quelli minimi $(0.014 \mathrm{~mm} / \mathrm{anno})$ alle dolomie.

\section{SUMMARY}

The current research on the dissolution of carbonate rocks in the Karst of Trieste indicates that the average degradation of surfaces exposed to atmospheric agents is 0.028 $\mathrm{mm} /$ year with an average rainfall of $1350 \mathrm{~mm}$. The maximum levels $(0.031 \mathrm{~mm} /$ year $)$ correspond to micro-crystalline limestones, the minimum values $(0.014 \mathrm{~mm} /$ year $)$ to dolomites.

\section{FOREWORD}

For 9 years, at eight experimental stations located in the Karst of Trieste (see Fig. 1), direct measurements have been taken on the degradation of the karst surface exposed to atmospheric agents.

The collection of data, performed every six months, relies on a special

(1) Research carried out thanks to $60 \%$ of MPI contributions (represented by F. Ulcigrai) for the academic years 1985, 1986 and 1987, in the framework of the "Karst Phenomena and Physical Caving"' section, of the national CNR Physical Geography and Geomorphology Group. .

\footnotetext{
* Istituto di Geologia e Paleontologia, Università di Trieste
}

** Commissione Grotte “E. Boegan”, S.A.G., Trieste 
micrometric instrument ${ }^{(2)}$ resting on stainless-steel nails driven into the rock (FORTI, 1981; see Fig. 2 and 3).

The preliminary results of the research have been reported on several occasions (see enclosed bibliography): the aim of this paper is to illustrate the available results graphically, to discuss the meaning of the measurements briefly and to compare data with the results available in the relevant literature, despite the different methods of data collection used.

\section{MEASUREMENT STATIONS}

Station nr. 1 is situated near the Grotta Gigante, next to the weather station chosen (see CLIMATIC FEATURES). It lies on an outcrop of Cretaceous fossiliferous limestone (wackestone sensu Dunham, biomicrite sensu Folk) with a $15^{\circ}$ slope. From the mineralogical point of view, the rock is made up of Calcite $(92.5 \%)$, Dolomite $(2.4 \%)$ with an insoluble residue of $5.1 \%$.

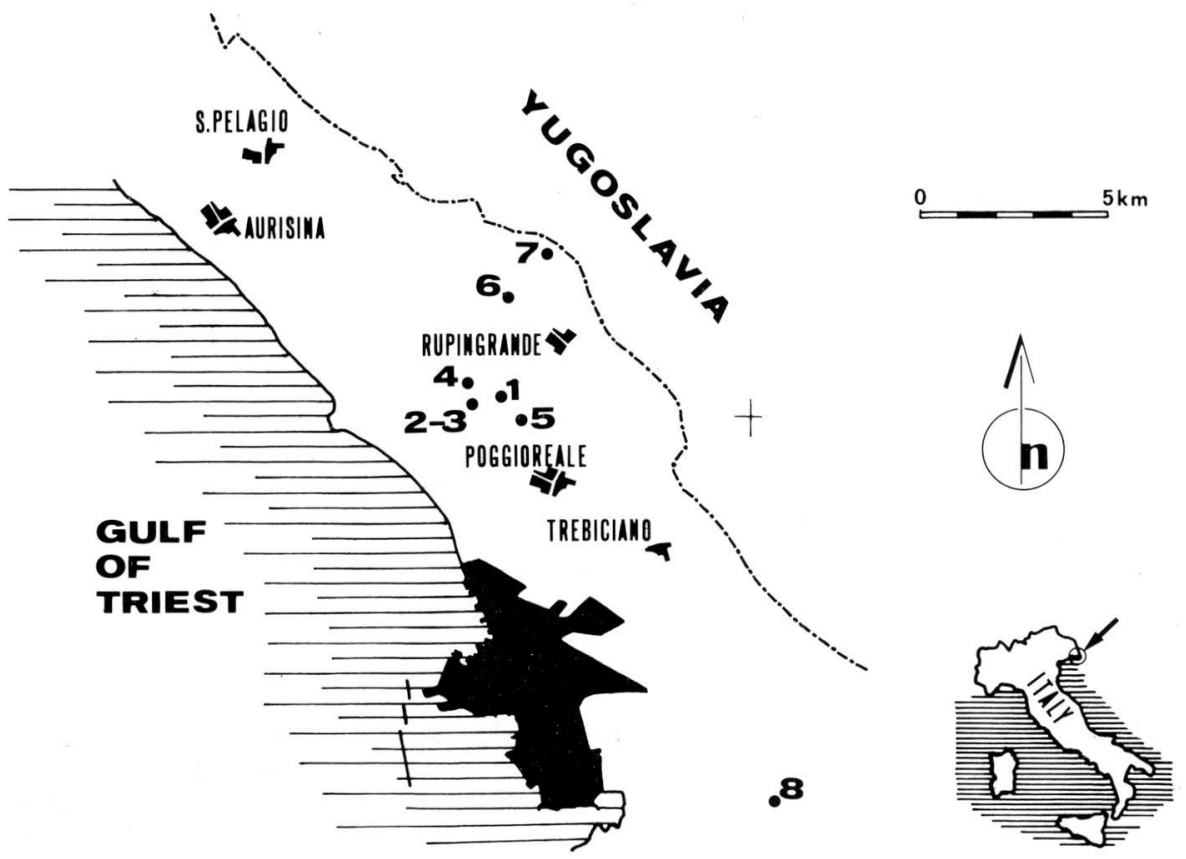

Fig. 1 - Location of measurement stations; the weater station is located next to measurement station nr. 1.

(2) The instrument is similar to that one developed in Bristol (HIGH \& HANNA, 1970). 
Station nr. 2 can be found in the surroundings of Borgo Grotta Gigante, standing on an outcrop of Cretaceous fossiliferous limestone (wackestone sensu Dunham, biomicrite sensu Folk) with a $10^{\circ}$ slope. From the mineralogical point of view, the rock is composed of Calcite $(91.0 \%)$, Dolomite $(2.5 \%)$ with an insoluble residue of $6.4 \%$.

Station nr. 3 is just a few centimeters away from station nr. 2 (and therefore lies on the same lithotype), but in the middle of a "kamenitza" $15 \mathrm{~cm}$ in diameter.

Station nr. 4 is located on the flank of a vast doline, on an outcrop of Cretaceous fossiliferous limestone with a $17^{\circ}$ slope. The rock has the same petrographic features as those of stations nrs. 2 and 3, with Calcite $(92.6 \%)$, Dolomite $(2.4 \%)$ and $5.0 \%$ of insoluble residue.

Station nr. 5 is situated near the conurbation of Opicina on an outcrop (see Fig. 2) of Cretaceous limestone (wackestone sensu Dunham, intrabiomicrite sensu Folk) which, after mineralogical analysis, have resulted to contain Calcite $(91.9 \%)$, Dolomite $(2.8 \%)$ and $5.3 \%$ of insoluble residue.

Station nr. 6 is located in a small valley on Cretaceous dolomites (anedral dolomite from biomicrite recrystallization) which, after chemical analysis, have shown to be made up of Dolomite (85.6\%), Calcite $(10.1 \%)$ and $4.3 \%$ of insoluble residue.

Station nr. 7 can be found on the eastern slopes of a ridge (Mount Lanaro) on an outcrop (see Fig. 3) of Cretaceous limestone (mudstone sensu Dunham, fossiliferous micrite sensu Folk) which, after chemical analysis, turned out to be composed of Calcite $(91.9 \%)$, Dolomite $(2.8 \%)$ and $5.3 \%$ of insoluble residue.

Station nr. 8 is located on the northern side of Mount Carso on the right handside of the Val Rosandra, on a subhorizontal outcrop of Palaeocenic limestone (packestone sensu Dunham, recrystallized biomicrite sensu Folk) which are mainly made up of Calcite $(93.0 \%)$ and Dolomite $(2.1 \%)$ with $4.9 \%$ of insoluble residue.

\section{CLIMATIC FEATURES}

The Karst of Trieste is characterized by a climate which is half way between the "Mediterranean type" and the "Continental type", with a long and cold winter, an unsettled spring and a hot summer extending over part of the autumn.

An official weather station is located by the entrance to the Grotta Gigante, i.e. very near to the measurement points 1,2 and 3. The relevant 


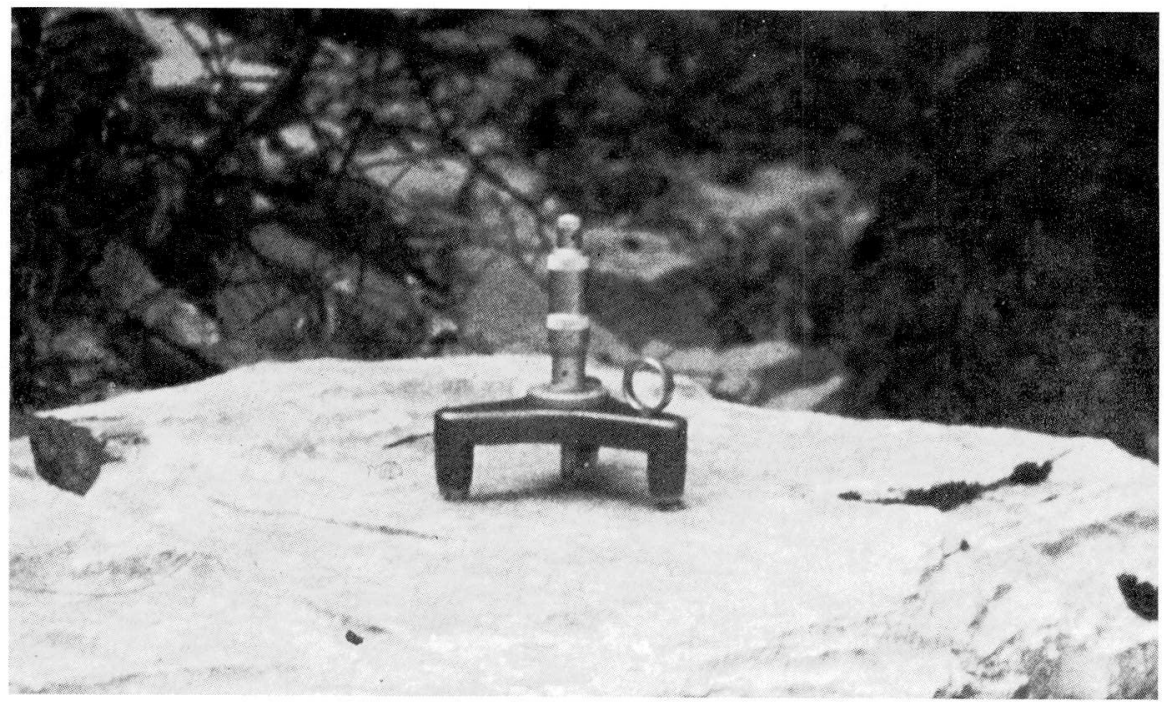

Fig. 2 - The micrometric instrument and station nr. 5.

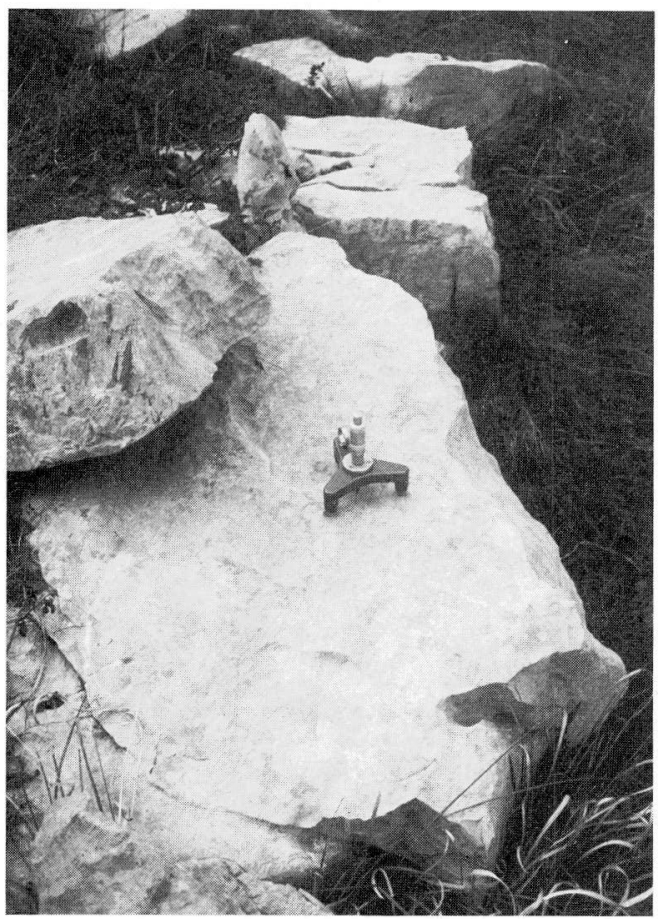

Fig. 3 - The micrometric instrument and station nr. 7 
observations have been under way for twenty years: the text makes reference to them and from them the daily precipitation data, reported for each of the various measurement stations, are drawn (GASPARO, $1980 \ldots$.. 1987).

The average rainfall is $1350 \mathrm{~mm}$ /year, with daily peaks of $105 \mathrm{~mm}$ recorded in autumn, in the month of November. The minimum values are recorded in winter, in the month of February. On average, there are 130 days per year when precipitation occurs, with a remarkable prevalence of rain (rain: $31.5 \%$; snow: $3.0 \%$; hail: $1.1 \%$; none: $64.4 \%$ ) (TOMMASINI, 1979; GASPARO, 1980 ... 1988).

Humidity generally ranges within rather low values, with maximum values in the late autumn and minimum values in July and August.

The average yearly temperature is $12^{\circ} \mathrm{C}$, with minimum and maximum daily temperatures of $-15^{\circ} \mathrm{C}$ and $+34^{\circ} \mathrm{C}$ respectively; during the winter months the average value is $3.5^{\circ}$, during the summer $19.5^{\circ}$.

The winds of the 1st Quadrant are the prevailing winds in terms of intensity and prevalence. In particular, the bora (ENE) is the most recurrent wind, with an average frequency of 78 days/year.

\section{RESULTS}

The diagrams illustrating the results of the measurements are given below (Figs. 4-11).

The measurements made in the various stations have been processed so as to obtain information on the features of the degradation due to karst phenomena.

It should also be underlined that the extremely limited values of the degradation can easily lead into errors when making measurements or, rather, they can sometimes produce measurements falling short of expectations.

However, all measurements have been transposed into diagrams, as very high degradation values or "accretion" values are all the same meaningful. Furthermore, instrumental or human errors are part of the experience.

During the 8 years of the experiment, 17-18 measurements were made at each station, which made possible to calculate an average 0.028 $\mathrm{mm} /$ year degradation of calcareous surfaces. The minimum degradation $(0.018 \mathrm{~mm} /$ year $)$ was recorded at station $\mathrm{nr} .8$, located on compact, fossiliferous, sparitic limestone; the maximum degradation $(0.031 \mathrm{~mm} /$ year $)$ was recorded at station nr. 4, situated on compact, micritic and partially fossiliferous limestone. 
In this respect, it should be mentioned that stations nrs. 2, 3 and 4 are located on rocks virtually having the same petrographic and mineralogical features. The absolute minimum degradation measured at station $\mathrm{nr}$. $3(0.012 \mathrm{~mm} /$ year $)$ is to be ascribed to the fact that the station lies on a "kamenitza" and, therefore, on a morphotype with a very limited vertical evolution.

Data referring to station nr. 6, located on dolomitic rocks, confirm the lower liability to karst phenomena of these lithotypes, although the recorded value $(0.014 \mathrm{~mm} /$ year $)$ is about 2.5 times lower than the values concerning calcareous lithotypes. These results have been corroborated by a recent research (STEFANINI et AL., 1985), consisting of a five-year exposure to atmospheric agents of about 40 " bricks" of various carbonate lithotypes.

If the measurements indicate a substantial increase in the degradation with the passing of time, it should also be recognized that when calculating the ratio between degradation $(\mathrm{mm})$ and quantity of precipitation in the period between measurements $(\mathrm{mm})$, the final result was nonetheless unexpected (Fig. 12). In short, the result is that there is no correlation between quantity of fallen precipitation and corresponding degradation, so much so that, for example, univocal degradations do not correspond to fundamentally equal precipitations.

The fact that the experience on the site contrasts with theoretical forecasts can have several explanations: different type and/or chemism of precipitations in the period considered, different average temperature, pressure, etc. Furthermore, and this subject will be dealt with later, there could also be differences in the exposed surfaces, which go unnoticed at a first observation. Preferring one explanation to another, however, seems premature. In the continuation of the experiment, once the data relating to 10 years of homogeneous measurements have been collected for all stations, all possibilities will be considered, also making correlations with stations of regions characterized by climatic features different from those of the Karst of Trieste.

As evidence of the research carried out, the reported diagrams indicate the results of the measurements taken at all stations, including the ratios between overall degradation and overall precipitation.

With regard to the ratios between relative degradation and quantity of precipitation in the period, only a few were chosen to represent non correlability. 


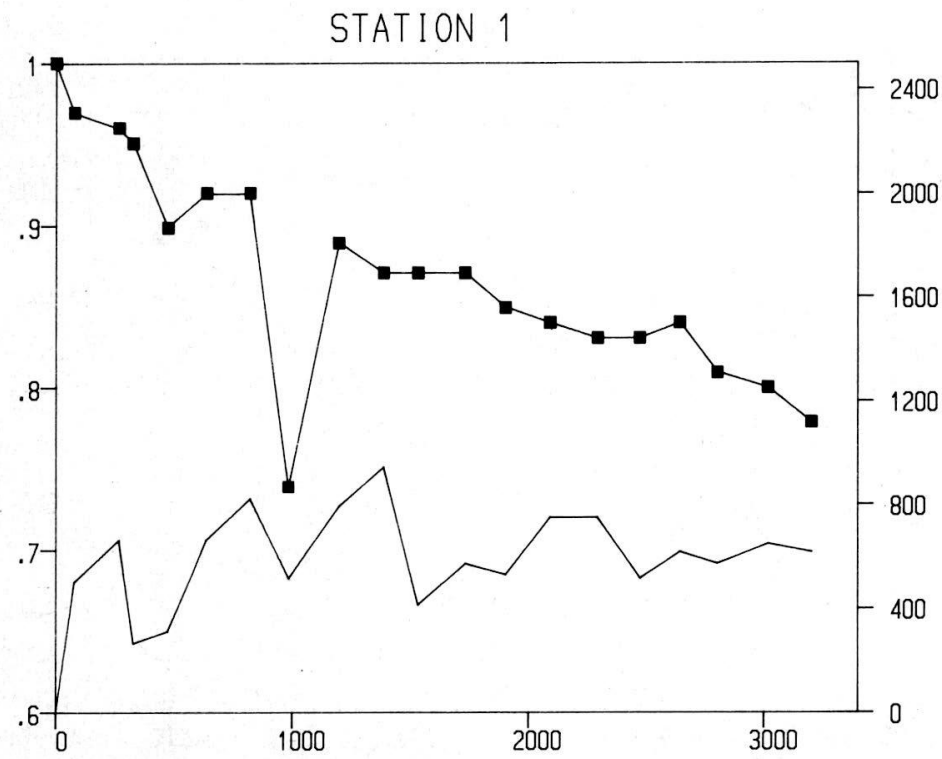

Fig. 4 - Station n. 1: relationships between relative degradation (in $\mathrm{mm}$, left $\mathrm{Y}$ - axis), rainfall (in $\mathrm{mm}$, right $\mathrm{Y}$ - axis) and time of exposure (in days, $\mathrm{X}$ - axis).

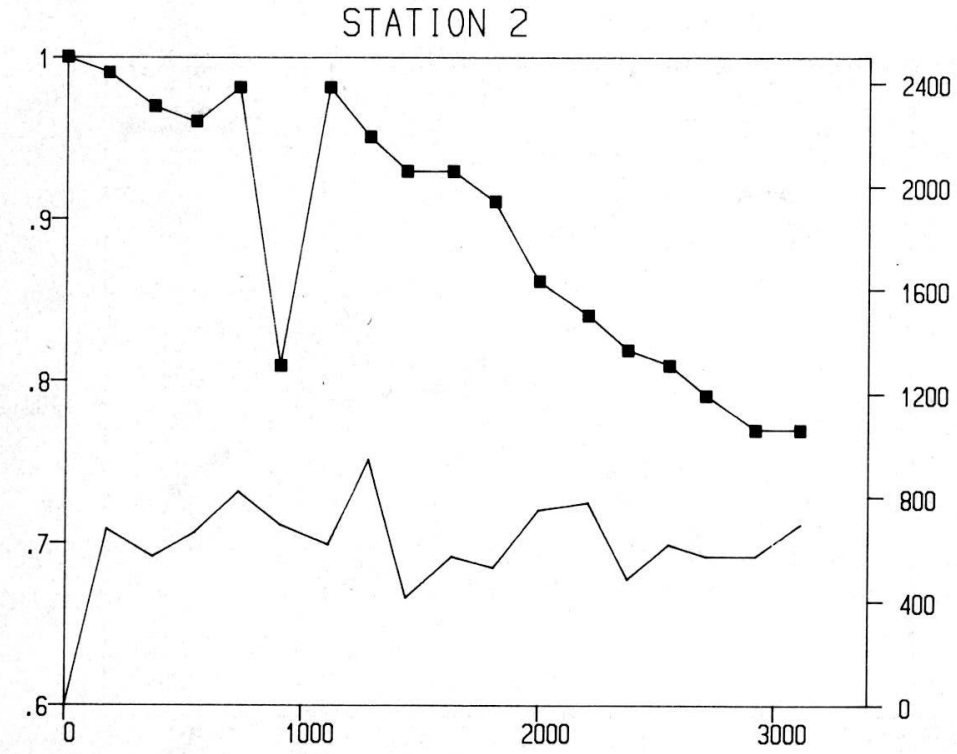

Fig. 5 - Station n. 2: relationships between relative degradation (in $\mathrm{mm}, \mathrm{Y}$ - left axis), rainfall (in $\mathrm{mm}, \mathrm{Y}$ - right axis) and time of exposure (in days, $\mathrm{X}$ - axis). 


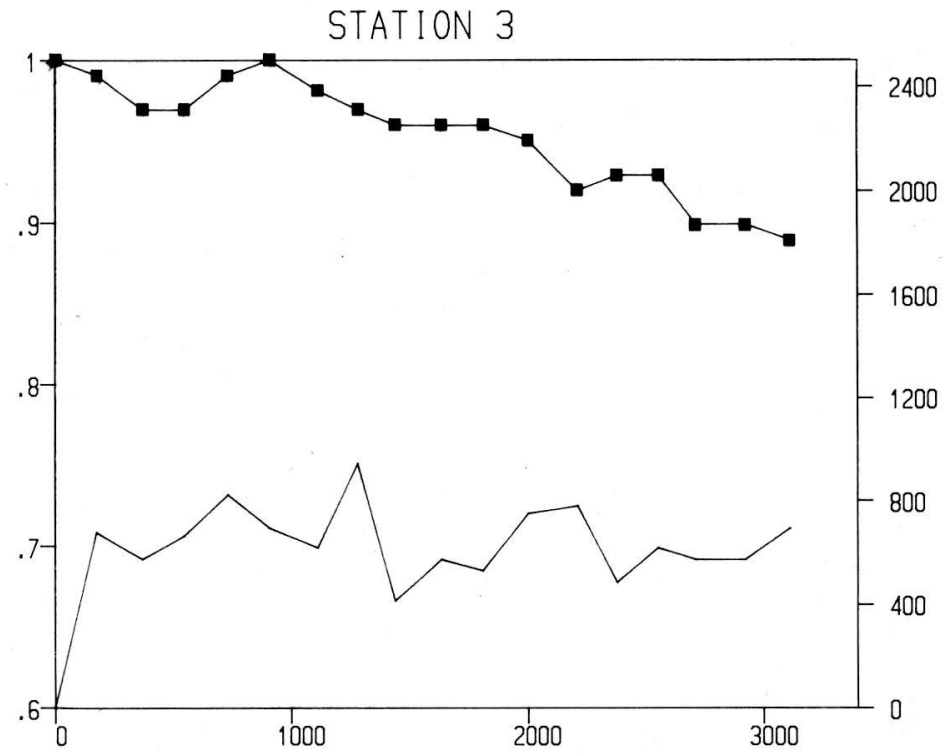

Fig. 6 - Station $\mathrm{n}$. 3: relationships between relative degradation (in $\mathrm{mm}, \mathrm{Y}$ - left axis), rainfall (in $\mathrm{mm}, \mathrm{Y}$ - right axis) and time of exposure (in days, $\mathrm{X}$ - axis).

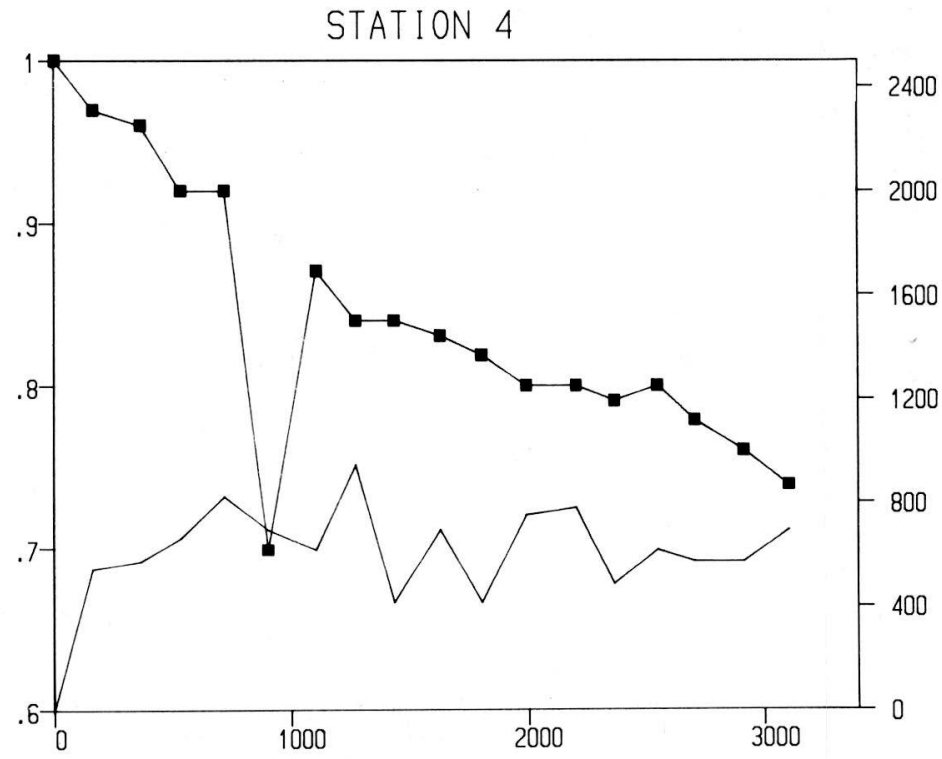

Fig. 7 - Station n. 4: relationships between relative degradation (in $\mathrm{mm}, \mathrm{Y}$ - left axis), rainfall (in $\mathrm{mm}, \mathrm{Y}$ - right axis) and time of exposure (in days, $\mathrm{X}$ - axis). 


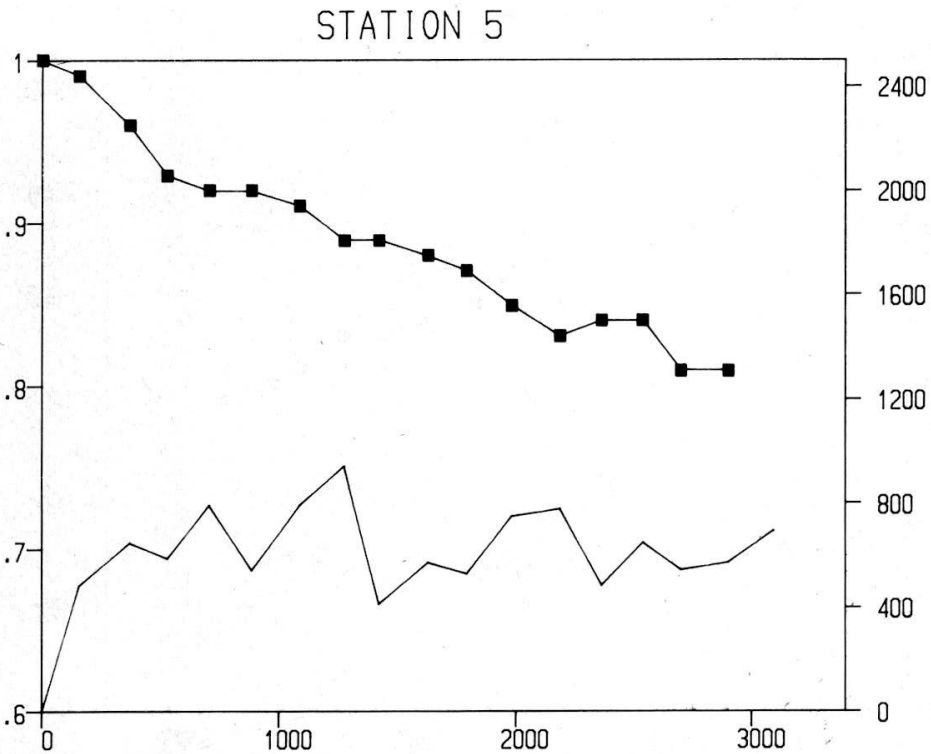

Fig. 8 - Station n. 5: relationships between relative degradation (in $\mathrm{mm}, \mathrm{Y}$ - left axis), rainfall (in $\mathrm{mm}, \mathrm{Y}$ - right axis) and time of exposure (in days, $\mathrm{X}$ - axis).

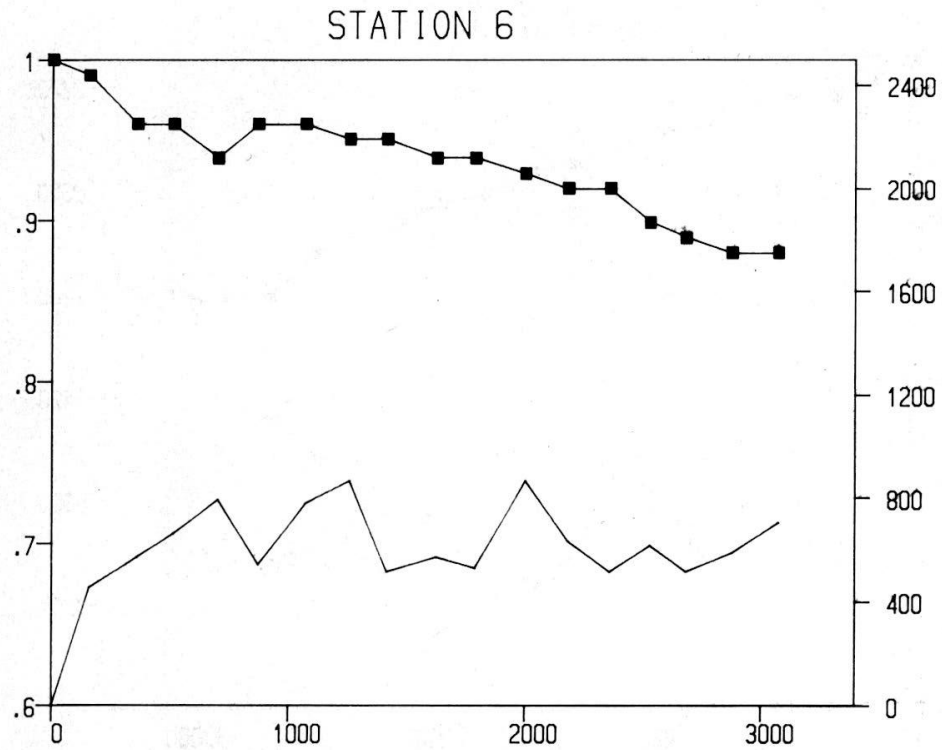

Fig. 9 - Station n. 6: relationships between relative degradation (in $\mathrm{mm}, \mathrm{Y}$ - left axis), rainfall (in $\mathrm{mm}, \mathrm{Y}$ - right axis) and time of exposure (in days, $\mathrm{X}$ - axis). 


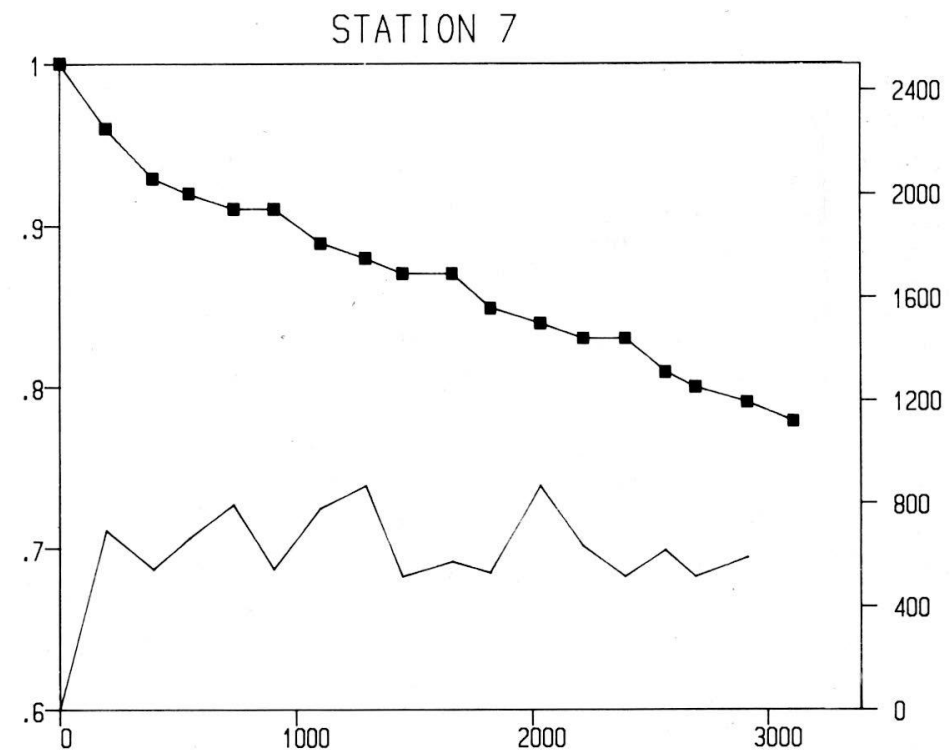

Fig. 10 - Station $\mathrm{n}$. 7: relationships between relative degradation (in $\mathrm{mm}, \mathrm{Y}$ - left axis), rainfall (in $\mathrm{mm}, \mathrm{Y}$ - right axis) and time of exposure (in days, $\mathrm{X}$ - axis).

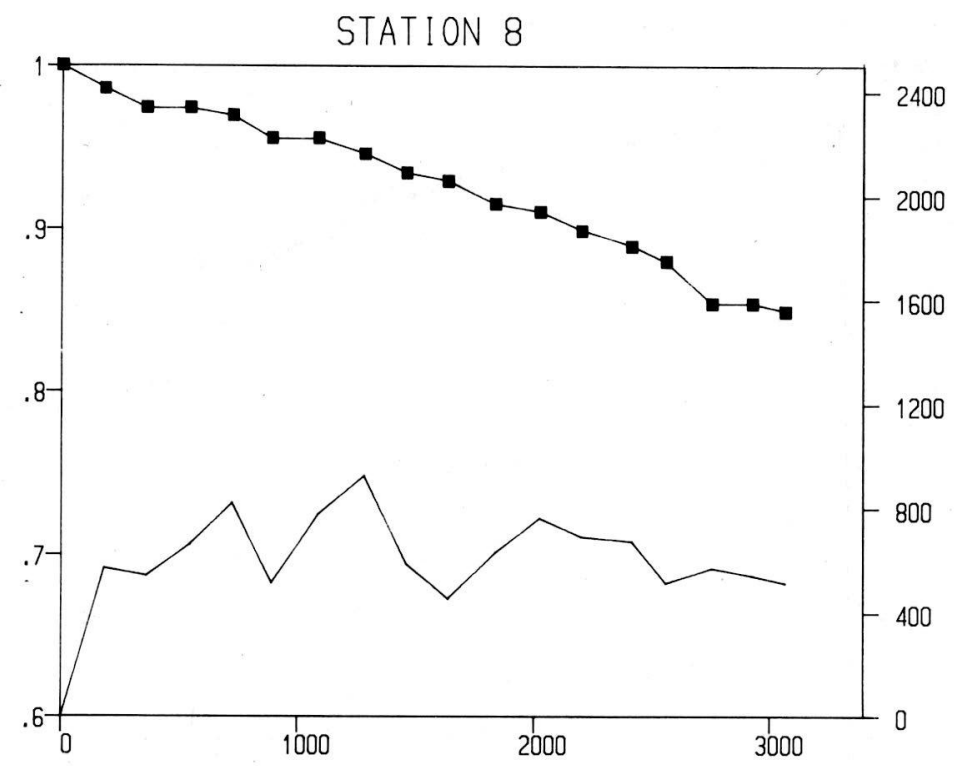

Fig. 11 - Station n. 8: relationships between relative degradation (in $\mathrm{mm}, \mathrm{Y}$ - left axis), rainfall (in $\mathrm{mm}, \mathrm{Y}$ - right axis) and time of exposure (in days, $\mathrm{X}$ - axis). 


\section{FINAL REMARKS}

The data assumed indicate that the current ratio of degradation of carbonated surfaces on the Karst of Triest is equal to nearly $2.8 \mathrm{~mm}$ every 100 years, implying an average weight loss due to surface erosion and corrosion of $18 \times 10^{-3} \mathrm{mg} / \mathrm{sq} . \mathrm{cm} /$ day.

Such value is about one unit of magnitude higher than the value obtained during the observations on "standard limestone tablets" performed under the aegis of the U.I.S. Commission on Karst Denudation (GAMS, 1985).

The average weight loss of rock samples having the same features and exposed to nearly identical morphological and climatic conditions, namely samples taken in Jugoslavia in the surroundings of Sesana, and Divaca, is more or less equal to $2.99 \times 10^{-3} \mathrm{mg} / \mathrm{sq} . \mathrm{cm} /$ day, although samples which had been exposed to atmospheric agents at a height of $+250 \mathrm{~cm}$ from ground level experience a loss ranging from $7.59 \times 10^{-3}$ to $11.32 \times 10^{-3}$ $\mathrm{mg} / \mathrm{sq} . \mathrm{cm} /$ day (GAMS, 1985).

During an observation, similar to the one performed by U.I.S., made on the Karst of Triest by using rectangular tablets having size of $6 \times 3 \mathrm{~cm}$ (STEFANINI et AL., 1985), corrosion was reported to cause average weight losses equal to $3.5 \times 10^{-3} \mathrm{mg} / \mathrm{sq} . \mathrm{cm} /$ day, which is very similar to the results arrived at by Gams in the standard limestone tablets experiment.

The values are very similar to the one measured by KUNAVER (1979) on Dachstein limestones of the M. Canin (YU), a hight alpine Karst with a total rainfall of $3.500 \mathrm{~mm} /$ year. Kunaver, using a Micro Erosion Meter, reports a mean ratio of degradation $0.035 \mathrm{~mm} /$ year (maximum value 0.102 $\mathrm{mm} /$ year, minimum $0.026 \mathrm{~mm} /$ year).

Other observations, such as the works by CRATBEE and TRUDGILL (1985), have produced values which cannot be correlated owing to the different methods used: in general, the weight loss values are substantially lower than those reported by the Authors.

PERNA and SAURO (1979) reported that, following direct monitoring on Karstic samples in Trentino (Italy) a degradation of calcareous surfaces in Italian alpine areas over the last 1,000 years can be assumed, ranging from $0.2 \times 10^{-3}$ to $35 \times 10^{-3} \mathrm{mg} / \mathrm{sq} . \mathrm{cm} /$ day, although the Authors deem that average values of $10 \times 10^{-3} \mathrm{mg} / \mathrm{sq} . \mathrm{cm} /$ day are more likely.

The "artificial" experiences, such as those performed on tablets, "plaquettes", etc. seem to yield dissolution values in default owing to the non-natural features of the surfaces exposed to atmospheric agents: when 

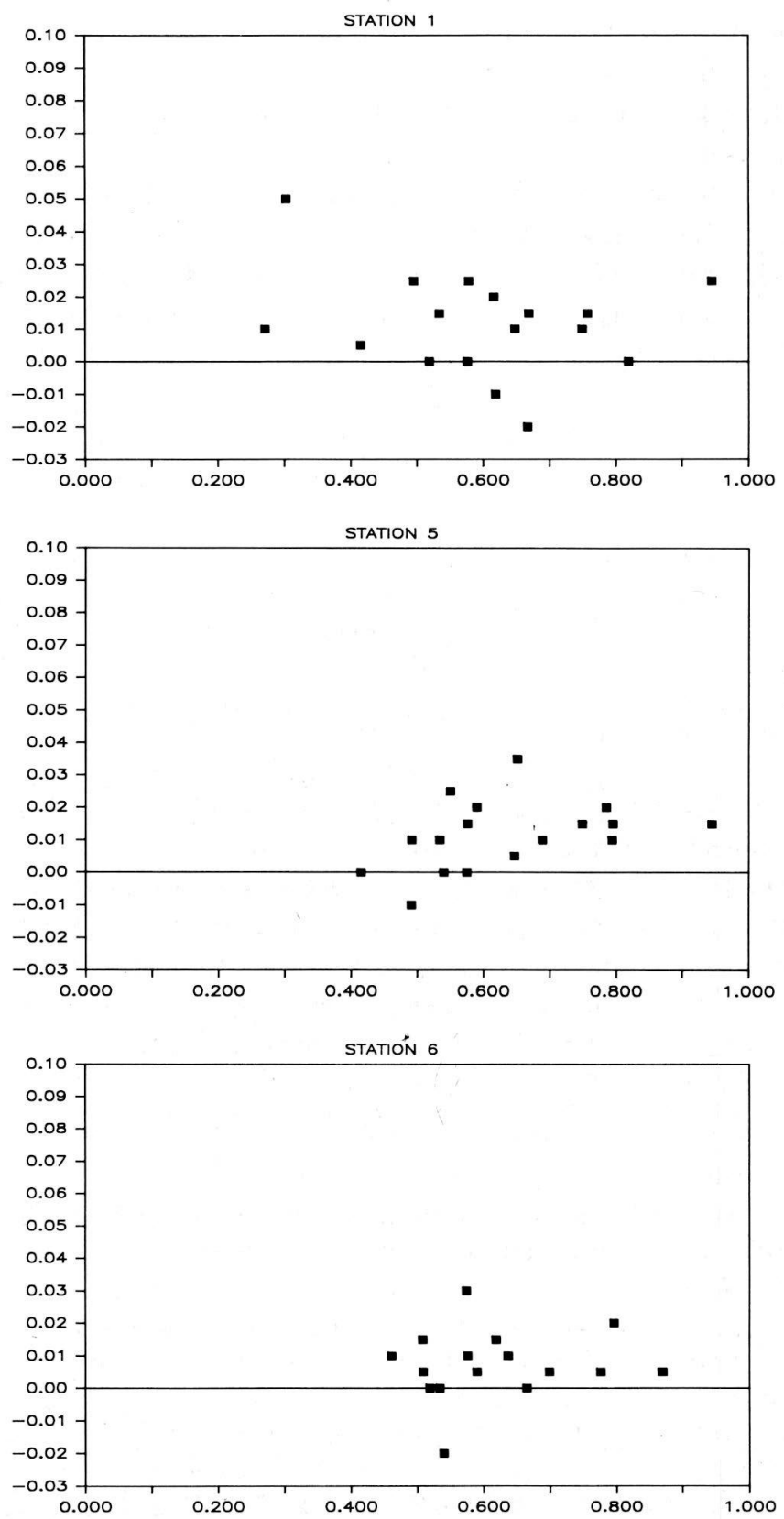

Fig. 13 - Stations n. 1, 5, 6: relationship between absolute degradation (in $\mathrm{mm}, \mathrm{Y}$ - axis) and rainfall (in $\mathrm{mm} \bullet 10^{-3}, \mathrm{X}$ - axis) relative to the same time period. 
samples are prepared in advance surface alterations, biological films, external intercrystalline porosity, etc. are eliminated with the result that the surface obtained substantially slows down the rate and extent of surface degradation.

Therefore "in situ" observations on samples which have not been previously prepared, are likely to yield more reliable results even though it must be acknowledged that the average weight loss values are defined indirectly and by means of methods which would have to be checked and compared.

\section{REFERENCES}

CORBEL J., (1959): Erosion en terrain calcaire. In: "Karst Geomorfology", edited by M. M. Sweeting (1981), 100-125.

CRABTREE R.W. AND TRUdGILl S.T., (1985): Chemical denudation on a magnesian limestone hillslope, field evidence and implications for modelling. Earth surface processes and landsform, Vol. 10, 331-341.

CUCCHI F. AND FORTI F., (1986): Misure di dissoluzione di rocce carbonatiche: le ricerche a Trieste. Atti e Memorie Comm. Grotte "E. Boegan", vol. 25 (1986), Trieste, 97102.

CUCCHI F. AND ForTI F., (1987): Misure in situ di dissoluzione di rocce carbonatiche. Atti X Congresso Nazionale Speleologia, Castellana, settembre 1987 (in press).

CUCCHI F., Forti F., STEFANINI S. AND UlCigRaI F., (1985): Mesures de érosion karstique et du concrétionnement dans le Karst de Trieste (Italie). In: Actes des "Journées Internationales de Karstologie", Metz (France), mai 1985. N. spec. di "Spelunca" (in press), Paris.

FORTI F., (1981): Metodologia per lo studio della dissoluzione con il sistema della misura con micrometro. Atti e Memorie Comm. Grotte “E. Boegan”, vol. 20 (1980), Trieste, $75-82$.

FORTI F., (1983): Misure della dissoluzione carsica e dell'accrescimento delle stalagmiti (nota preliminare). Atti $4^{\circ}$ Conv. Spel. F.-V.G., Pordenone 1979, Pordenone, 193-198.

FORTI F., (1984): Misure sulla dissoluzione delle rocce carbonatiche nella regione Friuli-Venezia Giulia. Atti $3^{\circ}$ Congresso Triveneto di Speleologia, Vicenza 1984.

FORTI F. AND STEFANINI S., (1981): Modalità di una prova sperimentale per la definizione del grado di solubilità dei principali litotipi del Carso Triestino sotto l'azione degli agenti esterni. Atti e Memorie Comm. Grotte 'E. Boegan", vol. 20 (1980), Trieste, 83-93. 
FORTI F., STEFANINI S. AND UlCIGRAi F., (1975): Relazioni tra solubilità e carsificabilità nelle rocce carbonatiche del Carso triestino. Atti e Memorie Comm. Grotte "E. Boegan", vol. 14, Trieste, 19-50.

GAMS I., (1985): International comparative measurements of surface solution by means of standard limestone tablets. Razprave IV, Razreda, XXVI (1985), 361-386.

GASPARO F., (1980, ..., 1987): Osservazioni meteoriche eseguite nel 1979, ..., 1986. Supplementi a Atti e Memorie Comm. Grotte “E. Boegan”, Trieste.

High C., HANNA F. K., (1970): Method for the direct measurement of erosion on rock surfaces. British Geomorphol. Research Group. Technical Bull., 5, Norwich.

KUNAVER J., (1979): Some experiences in measuring the surface karst denudation in high alpine environment. Actes du Symposium International sur l'érosion karstique. U.I.S. Aix en Provence-Marseille-Nimes, 1979, 75-85.

Perna G. AND SAURo U., (1979): Aspects de la dénudation karstique sur les "marocche". Actes du Symposium International sur l'érosion karstique. U.I.S. Aix en ProvenceMarseille-Nimes, 1979, 97-103.

PUlINA M., (1974): Denudacja chemiczna na obszarach krasu wenglanowego. Polska Akademia nauk. Inst. geografii, Prace geograficzne, 105, Wroclaw.

STEFANINI S., UlCIGRAi F., ForTI F. AND CUCCHI F., (1985):Résultats expérimentels sur les dégradement des principaux roches carbonatées du Karst de Trieste (Italie). In: Actes des "Journées Internationales de Karstologie", Metz (France), mai 1985. N spec. di "Spelunca" (in press), Paris.

Tommasini T., (1979): Dieci anni di osservazioni meteorologiche a Borgo Grotta Gigante sul Carso triestino (1967-1976). Suppl. Atti e Memorie Comm. Grotte "E. Boegan", 1979, Trieste, 1-11. 